\title{
Role of Lactic Acid Bacteria from Animal Products in Human Health - One Health Perspective
}

\author{
Carla Miranda ${ }^{1-3}$, Diogo Contente ${ }^{2}$, Gilberto Igrejas ${ }^{3-5}$, Sandra Paula de Aguiar e Câmara ${ }^{7}$, Maria de Lurdes Enes \\ Dapkevicius ${ }^{6,7 *}$ and Patrícia Poeta ${ }^{1-3}$
}

1 Microbiology and Antibiotic Resistance Team (MicroART), University of Trás-os-Montes and Alto Douro, Vila Real, Portugal; carlisabelmi@utad.pt (C.M.); diogo.contente95@gmail.com (D.C.)

2 Department of Veterinary Sciences, University of Trás-os-Montes and Alto Douro, Vila Real, Portugal

3 Associated Laboratory for Green Chemistry (LAQV-REQUIMTE), University NOVA of Lisboa, Lisboa, Caparica, Portugal; gigrejas@utad.pt (G.I.), Vila Real, Portugal

5 Functional Genomics and Proteomics Unit, University of Trás-os-Montes and Alto Douro, Vila Real, Portugal

6 Faculty of Agricultural and Environmental Sciences, University of the Azores, 9500-321 Angra do Heroísmo, Portugal; maria.ln.dapkevicius@uac.pt

7 Institute of Agricultural and Environmental Research and Technology (IITAA), University of the Azores, 9500-321 Angra do Heroísmo, Portugal; sandra.pa.camara@uac.pt

* Correspondence: maria.ln.dapkevicius@uac.pt (M.L.E.D.)

\begin{abstract}
Animal products, in particular dairy and fermented products, are natural, major sources of lactic acid bacteria (LAB). Due to their antimicrobial properties, LAB are used in humans and in animals, with beneficial effects, as probiotics or in the treatment of a variety of diseases. In livestock production, LAB contribute to animal performance, health, and productivity. In the food industry, LAB are applied as bioprotective and biopreservation agents, contributing to improve food safety and quality. However, some studies have described resistance to relevant antibiotics in LAB, with the concomitant risks associated to the transfer of antibiotic resistance genes to foodborne pathogens, their potential dissemination throughout the food chain, and the environment. Here, we summarize the application of LAB in livestock and animal products, as well as the health impact of LAB in animal food products. In general, the beneficial effects of LAB on the human food chain seem to outweigh the potential risks associated with their consumption as part of animal and human diets. However, further studies and continuous monitorization efforts are needed to ensure their safe application in animal products and in the control of pathogenic microorganisms, preventing the possible risks associated with antibiotic resistance and, thus, protecting public health.
\end{abstract}

Keywords: lactic acid bacteria; food-producing animals; dairy products; health benefits; One health; antimicrobial resistance; probiotics; starter cultures; adjunct cultures; protective cultures.

\section{Introduction}

The lactic acid bacterial (LAB) are an informal group of prokaryotes that share certain distinctive, morphological, metabolic, and physiological characteristics. They are non-respiring, aerotolerant, catalase-negative, fastidious cocci or rods. Most LAB are non-motile, non-sporulated, may grow at high salt concentrations, and at low $\mathrm{pH}[1,2]$. Their ancestors were, probably, soil bacteria similar to the Bacillus genus, which evolved towards adaptation to nutrient-rich environments, accumulating in the process multiple auxotrophies that rendered them fastidious $[3,4]$. They have, thus, complex nutritional requirements and need several growth factors, such as purines, pyrimidines, vitamins, and amino acids for their growth and metabolic activities. LAB obtain energy by fermenting carbohydrates (e.g., glucose). Based on the pathway for glucose fermentation, LAB are classified as homofermentative, which produce exclusively lactic acid as their final fermentation product, and heterofermentative, which produce acetic acid, $\mathrm{CO}_{2}$ and ethanol besides lactic acid $[1,2,5]$. A recently described group - the fructophilic LAB, present in fruits, flowers, 
and fermented foods - produce lactate, acetic acid, $\mathrm{CO}_{2}$, and ethanol when using fructose as a substrate [6].

The LAB are a genetically and ecologically diverse, but functionally related, group of genera belonging to the Lactobacillales order of the Firmicutes phylum and encompassing the Aerococcaceae, Carnobacteriaceae, Enterococcaceae, Lactobacillaceae (including those formerly part of the Leuconostocaceae), and Streptococcaceae families. In 2015, 40 bacterial genera were included in this group [7]; a recent revision of the taxonomy of the Lactobacillaceae, with the reclassification of the Lactobacillus genus giving rise to 23 new genera, substantially increased this number [8]. Although they belong to the Actinobacteria phylum, Bifidobacteria have been included in the LAB group by some authors, because both have probiotic potential and occupy similar ecological niches [9].

LAB are predominantly found in nutrient-rich habitats. They are part of the normal microbiota of the gastrointestinal tract (GIT) and of the vagina of animals and humans, constitute an important element of the non-starter microbial communities found in dairy products (e.g., milk, cheeses, kefir), fish, meat, and vegetables [1,2,6,10-12]. For instance, Oenococcus oeni plays a significant role in wine fermentation [13], whereas Lactiplantibacillus plantarum and Lactiplantibacillus pentosus are important for table olive fermentation [14]. On the other hand, LAB have been applied as starter/adjunct/protective cultures in dairy products (e.g., yogurt, cheeses), fermented meats, fermented vegetables, and fermented fish products [15-21]. They influence the organoleptic and nutritional characteristics of these foods, contributing to their distinctive flavors [11,22].

The unique characteristics LAB demonstrated in different biotechnological processes have fueled decades of research by the scientific community. This ongoing research effort has shown the importance of their ability to produce antimicrobial compounds for the control of pathogens, for health-promoting applications, in the process of food preservation, and in agroindustry [5,10,11]. The antimicrobial peptides, such as bacteriocins, produced by LAB have been used against pathogenic microorganisms involved in distinct infections and to control food fermentations [22]. Bacteriocins can be produced directly in the food through the starter, adjunct and/or bioprotective cultures, or they can be incorporated as preservatives, with the aim to improve food safety and quality $[1,10,22]$. LAB also hold promise as probiotics, which can aid in the management of pathological conditions, and as therapy adjuvants during the oral intake of antibiotics, by modulating the intestinal microbiota of the patients [23-26].

Several studies have described the positive effects of LAB on human and animal health, as well as in food industry and agriculture $[2,6,10]$. In foods, LAB contribute to preservation and innovation $[2,26]$. In humans, the daily consumption of fermented foods and food supplements containing LAB has shown a global increasing trend [26], due to their multiple, perceived benefits for human health [2]. The reported beneficial effects of $\mathrm{LAB}$ ingestion on human health mainly include the prevention of gut chronic diseases and colon cancer, immunomodulation, promotion of skin health, alleviation of allergic conditions, lactose intolerance, gastroenteritis, diarrhea, and peptic ulcer, inhibition of uropathogens, control of plasma cholesterol levels, and production of neurotransmitters (e.g., gamma-aminobutyric acid) [2,10,26,27].

In animals, LAB are also employed to obtain health benefits. The gut microbiota of animals can easily undergo dysregulation (dysbiosis) due to stress, medication, and changes in diet. As probiotics, LAB are used in cattle, other ruminants, swine, poultry, and in beekeeping to improve overall animal health, enhance growth, reproductive performance, and disease resistance [6].

Many studies have reported a diversity of LAB applications in the control of infectious diseases, both in animals and humans, due to their significant antimicrobial activity and probiotic properties. These antimicrobial effects have also been applied to control and inhibit foodborne microorganisms, promoting the safety and preservation of foods and feeds. However, few studies have investigated the impacts of antimicrobial-resistant LAB emergence in animal products on humans and on the environment $[28,29]$. The main aim of this review is, therefore, to summarize and highlight the application of LAB in livestock 
and animal products, as well as to discuss the implications of LAB presence in animal products on the health of their human consumers.

\section{LAB in livestock production}

In livestock production, $\mathrm{LAB}$ are introduced by the diet or as probiotic supplements [6]. These microorganisms, in particular L. plantarum, are used as the main crop silage additive that contributes to preserve the nutritional quality of ensilaged forages by inhibiting pathogenic microorganisms and promoting the early onset of lactic acid fermentation. Inoculating forages with homo- and heterofermentative LAB inoculants improved silage fermentation, decreased its final $\mathrm{pH}$, minimized the production of butyric acid and ammonia-nitrogen, as well as fungal and clostridial growth [30,31]. In addition, encapsulated LAB, such as Weissella paramesenteroides, have been applied in biological fish silage for aquaculture production [32].

At any age, perturbations of the native gastrointestinal tract microbiota can have severe consequences for the health, productivity, and development in production animals [33]. To improve animal health by combatting dysbiosis, LAB have been administered to production animals as probiotics, enhancing growth and reproductive performance. In animals, probiotics also show beneficial effects on the treatment or prevention of infectious diseases, can contribute to the reduction of antibiotic use, or be employed as antibiotic alternatives $[6,34]$.

The use of LAB as probiotics in livestock production has been the subject of numerous studies, in which novel strains with different origins and properties have been screened for use in several animal species. Dowarah et al. [35] isolated thirty LAB from piglet feces, most of which showed sensitivity to a variety of antibiotics such as penicillin, lincomycin, erythromycin, chloramphenicol, and clindamycin, but were resistant to vancomycin and ciprofloxacin. They showed in vitro antibacterial activity against Klebsiella oxytoca, Escherichia coli, Salmonella enterica, and Staphylococcus intermedius. In addition, Pediococcus acidilactici demonstrated potential probiotic properties in vitro, leading to higher nutrient digestibility, antioxidant activity, and improved hematological profile in weaned piglets [35]. A diet supplemented with $P$. acidilactici not only maintained balance in the gastrointestinal microbiota, but also enhanced the physicochemical properties of swine meat and carcass quality in comparison to Lactobacillus acidophilus supplementation $[36,37]$.

Supplementing the diet of lactating Holstein cows with L. acidophilus and a non-LAB bacterial species (Propionibacterium freudenreichii) induced better nutrient digestibility - in particular of crude protein, neutral, and acid detergent fiber - and increased milk production [38]. Frizzo et al. [39] reported that milk supplemented with probiotic lactic acid bacteria, such as L. acidophilus, L. plantarum, Ligilactobacillus salivarius, Enterococcus faecium, Lacticaseibacillus casei/paracasei or Bifidobacterium spp., improved feed use efficiency and increased body weight gain in young calves. In addition, L. acidophilus reduced diarrhea incidence in calves [38,40]. Another promising potential area of application of direct-fed $L A B$ in ruminant nutrition is in the mitigation of one of the main environmental impacts of milk and meat production - methane emissions [41].

In poultry production, the effects of dietary supplementations with probiotics are well documented $[34,42,43]$. However, further studies are still necessary to determine the mechanisms of action and assess the optimal dose for multi-strain probiotics. Besides improving the health status of these animals, the use of probiotics can provide an alternative to antibiotic growth promoters, banned by the European Union in 2006, thereby contributing to address a global public health concern - the antibiotic resistance crisis [34,43]. For example, P. acidilactici from rectal samples of poultry showed significant antibacterial activities against E. coli and S. enterica [44]. The application of LAB that have been selected on the basis of their in vitro immunomodulatory properties to control Salmonella infections in broilers proved to be advantageous. Feng et al. [45] reported that LAB with higher in vitro immunomodulatory activities, such as L. plantarum, L. salivarius, and P. acidilactici 
were more efficient on achieving a reduction of Salmonella counts in the intestinal tract and on minimizing its adhesion to and invasion of broiler livers and spleens. Moreover, broilers fed diets containing Lactobacillus showed lower cecal coliform counts, as well as lower cholesterol levels than the control group [42].

A diverse, numerous, LAB symbiotic community is present in the honey crop of bees, defending these important pollinators from the invasion by pathogens [46]. The application of LAB as prophylactics in beekeeping could enhance bee health, preventing infectious diseases, possibly contributing to prevent colony collapse disorder and, ultimately, increasing honey yield [11,46].

In general, when applied as probiotics, beneficial LAB have the following positive effects in animals: prevention against colonization by (antibiotic resistant) pathogens, modulation of the intestinal microbiota, reduction of inflammatory reactions, improvement of carcass traits, modulation of the immune response, performance enhancement, increase in nutrient digestibility and absorption, and decrease in urea and ammonia excretion (Figure 1) $[6,34,38,43]$. Therefore, dietary probiotics not only have effects on animal health and performance, but they also have potential commercial applications, with impacts on the quality of direct products and byproducts resulting from livestock production $[36,37,47]$.

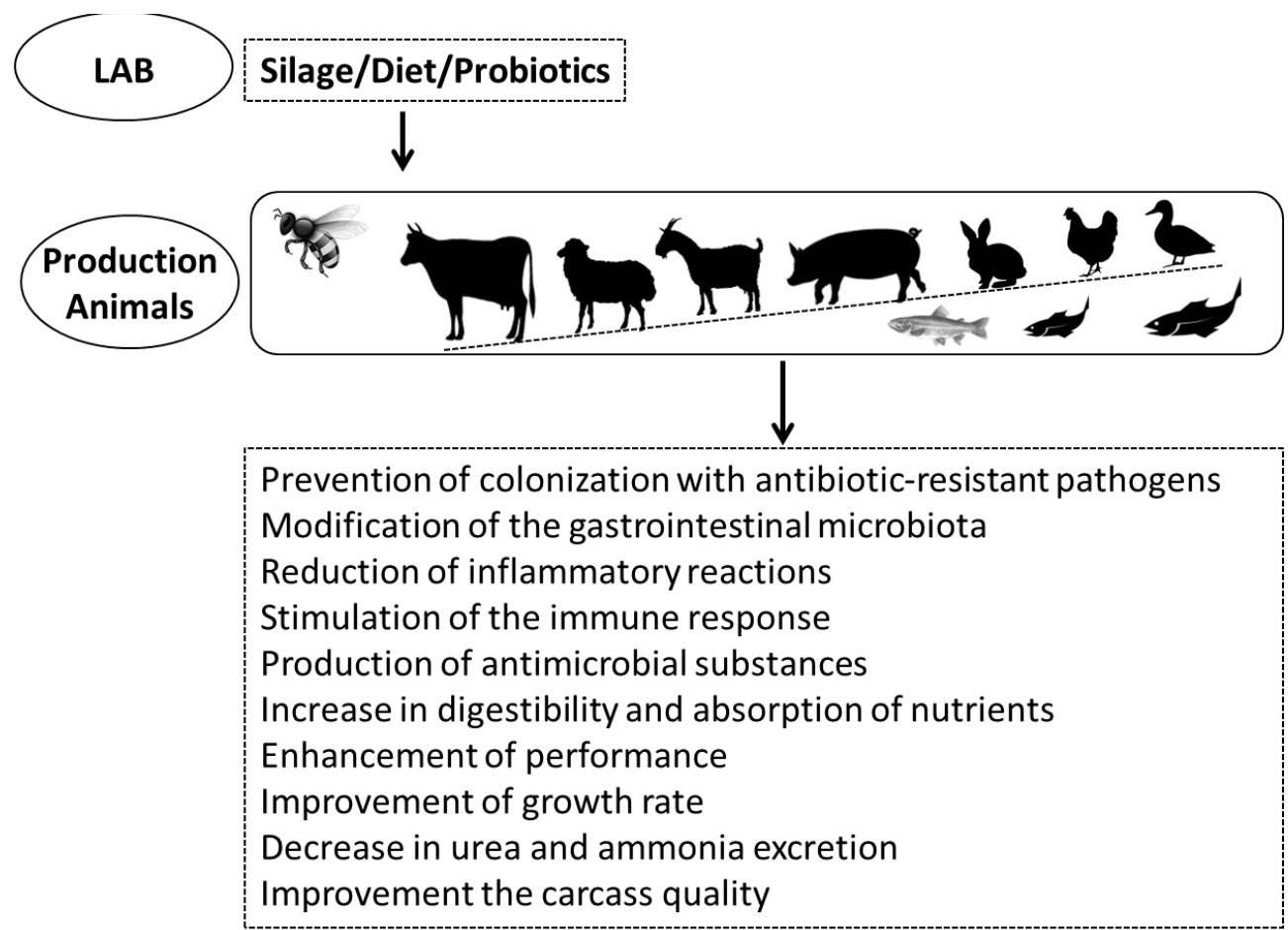

Figure 1. Main advantages of application of the lactic acid bacteria (LAB) in animal production.

\section{LAB applications in animal products}

A variety of LAB strains, that are either part of the autochthonous microbiota or introduced into animal products, have potential beneficial applications for the preservation of such products and/or for consumer health (Figure 2). Many foods obtained from fermented products of animal origin such as meat, fish, and dairy, contain living microorganisms that are phylogenetically similar to probiotic LAB as part of the microbiota that directs their fermentation process and is responsible for their unique character [48]. Fermented foods, such as cultured milk, yogurt, cheese, fermented sausage, and certain types of wine, are obtained through enzymatic reactions resulting from controlled microbial growth, in which the main microbial effectors comprise, primarily, LAB and their metabolites. During the fermentation process, transformation of the substrate takes place, bioactive or bioavailable metabolic end-products are formed, enhancing the organoleptic 
(flavor and texture) and nutritional (e.g., vitamin and protein content and bioavailability) properties of the fermentate, and antimicrobial metabolites (such as bacteriocins) can accumulate, reducing the risk of contamination with pathogenic microorganisms and contributing to the preservation of the end-product. In spite of these potentially beneficial results of the fermentative processes, the number of studies that evaluate the health benefits of including fermented feeds in animal diets is still very limited $[48,49]$.

In their fermentative processes, LAB - the main group of bacteria used for food and feed fermentations - release a number of bioactive metabolites, such as biogenic amines, exopolysaccharides, bacteriocins, and other biologically active, proteolytically released peptides [50-52]. Hetero- and homopolysaccharides produced by LAB have, respectively, immunomodulatory and prebiotic effects upon their animal hosts, and their industrial application has been studied [53]. LAB are fastidious microorganisms that require the presence of various free amino acids to grow. To ensure the supply of these essential nutrients, LAB possess proteolytic enzymes, bound to their cell walls, which degrade the proteins in the substrate, accumulating peptides and free amino acids. Some of the released peptides have been demonstrated to possess important bioactivities in the host [54]. For instance, bacteriocinogenic strains of LAB can be added to foods as starter cultures, co-cultures or bioprotective cultures, to improve food quality and safety, as reported in fermented meat and cheese [55,56]. They are also thought to play a role in the potential of LAB as growth promoters for animal production [57]. Besides their antimicrobial activity, peptides released by LAB have been described as possessing immunomodulatory and anti-hypertensive properties $[58,59,60,61]$, as well as activity as defensins [57] and as antioxidants [62].

During food fermentations, LAB are known to decarboxylate amino acids, leading to the accumulation of biogenic amines (BA) - histamine, cadaverine, putrescine, tyramine, and 2-phenylethylamine - under certain environmental circumstances. Enterococci, lactobacilli, streptococci, lactococci, pediococci and oenococci are regarded as the main BA producers in fermented foods, whereas leuconostocs and weisellae are thought to play a minor role. Decarboxylase activity is, however, a strain-related rather than a species- or genus-related trait [63]. On the other hand, there are reports of biogenic amine degradation by LAB due to their amino oxidase activity [51]. The application of BA degrading $\mathrm{LAB}$ could provide a means of controlling the accumulation of these toxins in foods and feeds [64].

Although LAB have demonstrated enormous environmental and health benefits in fermented food products, which could lead to an increase demand and consumption of such products, regulamentation has, in some instances, limited their application $[1,65,66]$. Some LAB (e.g., the enterococci) are still devoid of Qualified Presumption of Safety (QPS) and Generally Regarded as Safe statuses in the European Union and in the United States of America, respectively [67]. Although genetic determinants of virulence, such as genes encoding host adhesion factors, have been found in these bacteria, it still remains to be assessed whether these are virulence traits or merely reflect bacterial adaptations to promote host colonization as part of its beneficial microbiota [68]. The advances in functional genomics will contribute to fill this gap by providing a better understanding of the LAB-food/feed-host interactions [69]. 


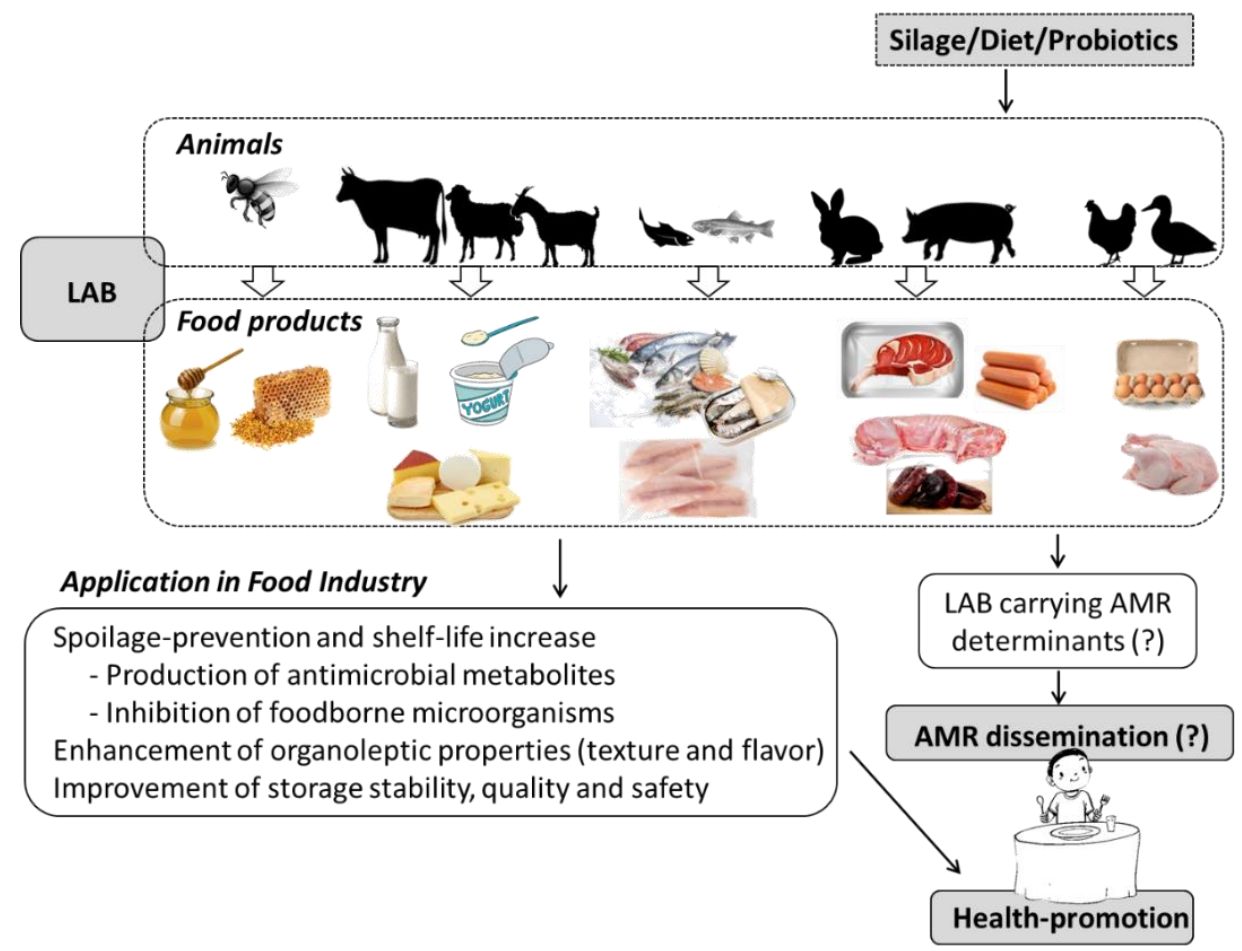

Figure 2. Application of lactic acid bacteria (LAB) in animal products for human consumption, and its implications for antimicrobial resistance (AMR) dissemination.

\subsection{Dairy products}

$\mathrm{LAB}$ are ubiquitous in the dairy environment and are an important part of the microbiota present in raw milk, fermented milks (such a yogurt, kefir, and viili), and cheeses $[2,70,71]$. A recent review reported a high LAB diversity isolated from traditional fermented dairy products, such as cheese, yogurt, kajmak, and sour cream, manufactured with bovine, ovine, and caprine raw milk without the addition of a starter culture. From the $28 \mathrm{LAB}$ species isolated, the most prevalent genera were Enterococcus, Lactobacillus (in its former taxonomic composition), Streptococcus, Lactococcus, Leuconostoc, Weissella, and Pediococcus [72].

Lactococcus spp. are the most frequently isolated LAB in artisanal dairy products $[73,74]$. In some artisanal, raw milk cheeses, lactococci predominate and possibly conduct the maturation processes $[72,75,76]$. The most commonly found lactococcal species is Lactococcus lactis $[72,77,78]$, with the occasional presence of Lactococcus raffinolactis and Lactococcus garviae [78]. The main role of lactococci in dairy products is to promote acidification by metabolizing lactose, chiefly to L-lactic acid, and to produce flavor compounds (alcohols, ketones, aldehydes) from milk proteins, lipids, and citrate. Acidification is one of the barriers that contribute to the preservation of several dairy products, but certain lactococcal strains also produce bacteriocins with impact on this aspect [79]. Albeit it is not common, their use as probiotics has been considered [80]. Lactococci bear both the GRAS and the QPS status. They have been widely used as starter cultures in the dairy industry, particularly Lac. lactis, but also, to a lesser extent, Lac. raffinolactis [81]. Fermented dairy products constitute an important source of lactococci for the human host, with the estimated annual ingestion of lactococcal cells by human consumers reaching up to $10^{8}$ cells [82].

Lactobacilli (including all 25 genera in which they have recently been reclassified by Zheng et al. [8]) are frequently isolated from raw milk and fermented dairy products. In most cheeses, lactobacilli are part of the native microbiota, with several species represented. Ten lactobacilli species have been reported in Portuguese artisanal cheeses, manufactured without the addition of a commercial starter: L. casei [83,84], L. paracasei [83-87], Latilactobacillus curvatus [84], L. plantarum [84-87], L. acidophilus, Lactobacillus delbrueckii [84], Lentilactobacilus otakiensis [83,85,86], Levilactobacillus brevis, Limosilactobacillus 
fermentum [84]. Lactobacilli, for example, L. paracasei, Lacticaseibacillus rhamnosus, L. plantarum, and L. curvatus play a role in cheese ripening [73]. In other fermented dairy products, a variety of lactobacilli have also been reported, such as L. delbruecki in yogurt [73] and Lentilactobacillus kefiri, the most representative of the former Lactobacillus species in kefir, a fermented milk drink from the Caucasus Mountains. The kefir grain includes other lactic acid bacteria, such as L. brevis, L. paracasei, Lactobacillus helveticus, Lactobacillus kefiranofaciens, L. plantarum, L. kefiri, Lac. lactis, Streptococcus salivarius subsp. thermophilus, and Leuconostoc mesenteroides, besides acetic acid bacteria and yeasts. During fermentation, the production of lactic acid, ethanol, flavor-generating components, and carbon dioxide are responsible for the unique kefir sensorial characteristics. Kefir demonstrated health benefits on the gastrointestinal microbiota and function, as well as in vitro antimicrobial activity against several pathogens, such as Staphylococcus aureus, Enterococcus faecalis, S. enterica, E. coli, Shigella sonnei, Bacillus subtilis, and Candida albicans [48]. L. delbrueckii and L. helvet$i$ icus are the main lactobacilli used as starter cultures in the dairy industry. Probiotic properties have been attributed to several lactobacillus species. For instance, Pino et al. [88] isolated $166 \mathrm{LAB}$ from Piacentinu Ennese cheese after 90 days of ripening, indicating $L$. paracasei and L. rhamnosus as the main LAB species with promising probiotic properties. Dairy products have been frequently used as carriers for probiotic lactobacillus strains, such as L. acidophilus and L. rahmnosus [89]. Many, but not all, of the species included in the lactobacillus group of genera possess QPS status [90].

Leuconostocs are part of the core microbiota in several artisanal cheeses, albeit their populations are, in general, numerically lower than those of lactococci [83]. The main species described in starter free cheeses from Portugal were Ln. mesenteroides, Leuconostoc lactis [84], Leuconostoc pseudomesenteroides [83], and Leuconostoc citreum [85]. All of these leuconostoc species possess QPS status. Leuconostoc spp. participate in the maturation of nonhard cheese varieties, including Camembert, where they may contribute to flavor formation, to their rheological properties by producing exopolysaccharides, and/or to open texture due to $\mathrm{CO}_{2}$ production $[38,91,92]$. Ln. lactis and Ln. mesenteroides are used in the production of butter, sour cream, and other non-maturated dairy products [91]. Probiotic potential has been described in leuconostoc strains isolated from dairy products [85]. Dairy products may serve as a considerable source of leuconostocs for the human host. Firmesse et al. [92] reported high levels of Lac. lactis and Ln. mesenteroides in fecal samples during the consumption of Camembert cheese, which, in the case of Ln. mesenteroides, persisted 15 days after the end of consumption.

Enterococci are members of the non-starter microbiota in many artisanal cheeses, where their role in flavor development has been documented [67,93]. A total of 19 species have been described in artisanal cheeses so far - Enterococcus avium, Enterococcus casseliflavus, Enterococcus devriesei, Enterococcus durans, E. faecalis, E. faecium, Enterococcus gallinarum, Enterococcus gilvus, Enterococcus hirae, Enterococcus italicus, Enterococcus lactis, Enterococcus malodoratus, Enterococcus mundtii, Enterococcus pallens, Enterococcus pseudoavium, Enterococcus ratti, Enterococcus saccharominimus, Enterococcus sulfureus, and Enterococcus villorum [67]. Their potential as starter cultures, however, is much less evident. Not only they often lack the desirable acidification and proteolytic capacity, but also none of the species in this genus has yet been granted GRAS/QPS status. The opportunistic potential of enterococci has weighed in this decision. However, food enterococci seem to differ considerably in their virulence from clinical isolates and further studies might allow the use of certain enterococci in food settings. Dairy enterococci could provide a promising reservoir of bacteriocin-producing strains with the potential to modulate the microbiota of cheeses, that could be used as protective cultures, thereby promoting their safety [67]. The potential of several enterococci as probiotics has been reported, both for human and animal applications, but the aforementioned safety concerns have limited their commercial application $[67,94]$.

Certain streptococci, such as Strep. salivarius ssp. thermophilus [1] and Streptococcus gallolyticus subsp. macedonicus [95], are part of the LAB, possess QPS status, and are commonly present in dairy products. Strep. salivarius subsp. thermophilus is typically used as a 
starter culture to ferment milk, usually of ruminant origin, giving rise to a diversity of products with unique flavors, textures, and nutritional properties [1]. In yogurts, it is symbiotically associated with $L$. delbrueckii, where this bacterial consortium acidifies the milk and produces acetaldehyde - a key compound for the flavor of this product. In cheeses, it also contributes to acidification of the curd and to flavor formation during ripening. Furthermore, there are reports of EPS and bacteriocin production by this species, as well as probiotic characteristics [96].

Dairy products can act as reservoirs of lactic acid bacteria for their human consumers. The lactic acid bacteria in these products may impact human health, with several species included in this group presenting potential as protective and/or probiotic cultures. Bacteriocin production is of particular interest in this respect. Pathogenic microorganisms found in raw milk, like Staph. aureus, E. coli, Listeria monocytogenes, and Salmonella sp., can be transferred from livestock animals to humans through the consumption of milk and dairy products, causing severe diseases. Although the bacterial contaminants in milk are largely eliminated by the pasteurization process, the application of LAB producing bacteriocin-like compounds in fermented and nonfermented dairy products could improve their quality and safety, decreasing the associated food-borne infection risks [97]. The bacteriocin-type compounds (e.g., lactocidin, acidolin, and acidophilin) produced by L. acidophilus have a broad spectrum of inhibitory activity against species of Gram-negative and Gram-positive bacteria (Salmonella, Shigella, Clostridium, Staphylococcus, Listeria), yeasts (Candida), and protozoa (Trypanosoma) in dairy products [1]. Moreover, lacticin produced by Lac. lactis inactivated L. monocytogenes in cottage cheese and yogurt. Nisin, the best known of the bacteriocins produced by Lac. lactis, demonstrated bactericidal activity against L. monocytogenes and Clostridium in milk, preventing the spoilage process known as late blowing in cheese $[97,98]$. A recent study reported that the major bioprotective mechanism responsible for the inhibition of deteriorative microbiota in fermented dairy products by members of the former Lactobacillus genus is through competitive exclusion by expression of the mntH1 gene. This novel and natural mechanism was demonstrated to inhibit the growth of spoilage microorganisms, such as molds and yeasts, in dairy products (e.g., yogurts) [99]. It can be concluded that autochthonous dairy LAB exhibit unique technological and health-promoting properties, including probiotic activities, production of flavor compounds, bacteriocins, and other bioactive peptides, demonstrating their potential for the production of novel, health-promoting foods [72].

\subsection{Meat and fermented meat products}

Meat products harbor a diverse LAB microbiota, in which lactobacilli (Latilactobacillus sakei, L. curvatus, and L. plantarum) usually predominate [100] and play an important role in maturation. In certain cases, considerable populations of leuconostocs (Ln. mesenteroides, Leuconostoc carnosum) and enterococci (E. casseliflavus) are also present [101,102]. Meat fermentation is a complex process, from the point of view of its microbial ecology, in which both LAB and coagulase-negative staphylococci intervene, participating in the development of the typical sensorial properties of the product and in its biopreservation [103].

LAB can either be used as meat starter cultures and/or as probiotics, interacting with native microorganisms in the product, or they can be part of the non-starter microbiota in fermented products. In both cases, their presence can have potential advantages for the end-products [104,105]. Fermentation allows to preserve meat products and to create a variety of fermented meats with different organoleptic characteristics, as a result of the microbial and endogenous enzymatic reactions taking place within their primary component - the animal muscle. The use of starter cultures, including probiotic microorganisms with health-promoting potential, such as the ability to reduce cholesterol content, contributes to promote product stability and safety, as well as consumer acceptance [105-107].

Several criteria should be considered to select LAB for the production of fermented meats. The ability to acidify and grow at low $\mathrm{pH}$ values are desirable factors for potential 
starter cultures for the meat industry and for spoilage-prevention, because they lead to increased safety and prolonged shelf life of the final products by inhibiting the growth of pathogenic and deterioration microorganisms, facilitating maturation, ensuring microbial stability during storage, stabilizing the product color, and improving its texture. Another desirable trait is proteolytic activity, which plays an important role in flavor development during the fermentation process, as is the case in raw sausage fermentation. During meat fermentation, LAB can positively influence protein degradation. The resulting peptides can be further converted into volatile compounds, important for the sausage flavor [105107]. Proteolytic activity, acidification, and the ability to produce low final $\mathrm{pH}$ values were observed in LAB, particularly in lactobacilli, isolated from Bulgarian traditional fermented lulanka salami, manufactured from veal, pork, and spices encased into dried bovine intestines [105]. The analysis of the most popular dry fermented sausages in Spain, chorizo and salchichón (that mainly included minced pork and deer meat), demonstrated that the final $\mathrm{pH}$ value attained, and the amount of lactic acid produced, influenced microbial counts in these meat products [108]. The antimicrobial activity of LAB is another desirable trait, since inhibition of the proliferation of spoilage bacteria and foodborne pathogens is important to ensure product quality, shelf life, and safety [107]. Todorov et al. [105] reported the presence of antimicrobial activity in L. plantarum and L. brevis from traditional salami against L. monocytogenes, an additional advantage for the product biopreservation. Moreover, antimicrobial activity against other tested LAB, such as Lactococcus spp., Pediococcus spp., and Enterococcus spp., was not observed. In addition, few strains in this study showed the presence of genes for virulence factors, biogenic amine production, and resistance to vancomycin. On the other hand, a high prevalence of bacteriocin genes was detected. Other beneficial properties to take in account when screening LAB to add into fermented meat products include the ability to degrade biogenic amines [109], cholesterol [110], and carcinogens in meats [111], particularly in smoked meat products [112], as well as the capacity to control lipid oxidation [112].

Several of the LAB associated with fermented meats are bacteriocinogenic and possess, therefore, the ability to modulate the microbiota of the product, combatting the proliferation of pathogenic (L. monocytogenes, E. coli O157:H7, Salmonella spp., and Clostridium botulinum) and deterioration microorganisms [113]. Meat products often rely on hurdle technology for their safety and preservation; bacteriocins can, in this context, provide an additional hurdle. Bacteriocinogenic L. curvatus has been successfully employed to extend the shelf life and improve microbial safety in meats, effectively controlling L. monocytogenes and Brochothix thermosphacta in fresh beef, without negatively impacting its sensory properties [114]. Leroy et al. [115] demonstrated that L. sakei isolated from sausage produce the sakacin $\mathrm{K}$ bacteriocin, that is active against some listerial strains, leading to inactivation of Listeria innocua during the sausage fermentation process. In another study, 813 bacteriocin-producing LAB strains that demonstrated the ability to inhibit the growth of L. innocua and Staph. aureus were isolated from 174 meats and meat products [109]. Of these, five bacteriocin-producing strains, including Lac. lactis and L. plantarum, were analyzed in greater detail. All of them displayed traits consistent with probiotic potential, such as tolerance to very low $\mathrm{pH}$, survival/growth at gastrointestinal tract and at food storage temperatures, as well as biofilm production [48]. Although the probiotic potential of autochthonous meat LAB has been demonstrated, fermented meat products are not a common vehicle for probiotic bacteria. The conditions within their matrices ( $\mathrm{pH}$ values, water activity, inhibitory concentrations of $\mathrm{H}_{2} \mathrm{O}_{2}$, organic acids, sugars, and additives) have a negative effect on probiotic viability. However, selection of the adequate strains and/or techniques such as microencapsulation might help probiotic LAB survive under these conditions, enabling their addition to fermented meats [116,117].

In certain cases, LAB have been associated with deteriorative processes in meats. Certain carnobacteria, lactobacilli, leuconostocs, weissellae, and lactococci can lead to acidification, produce off-odors, blowing of packages, slime, and green discoloration in fresh meats [118]. Regarding their antibiotic resistance/sensitivity profile, resistance to 
erythromycin was common; resistance to vancomycin, chloramphenicol, tetracycline, and chloramphenicol was present in a few strains [119].

\subsection{Fish and fishery products}

Fish and seafood are an important part of the human diet. These foods harbor a numerically low, but diverse, community of authochthonous LAB, in which lactobacilli, lacotocci, leuconostocs, enterococci, streptococci, carnobacteria, weissellae, and pedicocci have been identified [120]. For instance, Companilactobacillus farciminis, L. sakei, and Companilactobacillus alimentarius were identified in smoked trout, cooked coldwater shrimp, and cold-smoked salmon [121].

Fish and seafood can spoil very rapidly; the required hygienic quality and safety standards are, therefore, difficult to maintain. Due to the production of antimicrobial metabolites, such as organic acids and bacteriocins, LAB can be regarded as natural biopreservative agents, although scarce commercial applications of these bacteria have been developed from/for fish and fishery products [121]. LAB of marine origin and their metabolites possess, however, a major potential as fish biopreservatives, due to the abundance of antimicrobial mechanisms they are able to deploy: acidification, bacteriocins, lysozymes, proteases, siderophores, and/or hydrogen peroxide production [121]. Furthermore, they are abundant in the microbiota of many fish species, and most LAB genera are recognized as safe [21,122]. The application of LAB biopreservative potential in fish and fishery products has been demonstrated in several works. For instance, the addition of L. curvatus and E. faecalis, through the production of their bacteriocins, sakacins and enterocin respectively, was shown to improve the organoleptic properties, inhibit L. monocytogenes, and increase the market value of young hake and megrim. L. sakei also showed activity againts L. monocytogenes [51]. Additionally, Sarika et al. [123] demonstrated that bacteriocin PSY2 from Lac. lactis, isolated from marine perch, provided extende shelf-life and better protection against spoilage bacteria in reef cod fillets. Autochthonous LAB belonging to the Aerococcus, Carnobacterium, Leuconostoc, and Vagococcus genera, applied in conjunction with chitosan, modified atmosphere packaging, and superchilling, proved to be an efficient additional hurdle against several fish deteriorating bacteria (Shewanella baltica, Photobacterium phosphoreum, B. thermosphacta, L. sakei, Hafnia alvei, and Serratia proteamaculans) [124]. Application of LAB to fishery products as biopreservative cultures could, therefore, provide an additional hurdle for preservation and safety assurance in these highly perishable commodities. As in other food commodities, bacteriocin production is an important trait in the screening for LAB destined to be used as biopreservatives for fishery products [21].

Fermented fish products are not an important component of Western diets. In Asia, however, traditional fermented fish products, such as plaa-som, hoi-dorng, som-fak, para, pla-chom, kung-chom (Thailand), bekasam, chao (Indonesia), chouguiyu (China), burong baugus, burong isda (Philippines), budu, pekasam (Malaysia), ngari, hentak, tungtap (India), may constitute important sources of dietary protein [125]. Fermentation also provides a means of upgrading fish waste and by-catch, an important issue in an industry that discards up to $70 \%$ of its captures $[51,126,127]$. The resulting fermentate can be utilized as feed for certain animal species [51,126], as a protein hydrolysate for microbiological culture media [128], or as fertilizer for organic farming [129]. Besides of the technological properties required for the fermentation of other food matrices, LAB must also be able to limit the accumulation of biogenic amines in fermented fish products. These microbial metabolites are of particular concern in fish species (such as those belonging to the Scombridae family) that are rich in their precursor amino acids [51].

\subsection{Other animal products}

The application of dietary LAB in apicultural and poultry production has demonstrated promising effects on animals, their products, and their human consumers. Mikulski et al. [47] reported that a diet supplemented with P. acidilactici in the early laying 
phase improved the market value of carcasses and eggshell quality. A significant decrease in the number of broken shells, absent shells, and downgraded eggs, as well as an increase in egg weight, relative weight, and thickness of the eggshells were observed. In addition, probiotic supplementation improved feed efficiency ratio and hen performance. However, the main objective in studies on probiotic application in egg production has been to reduce the cholesterol content of this product. Several studies have demonstrated evidence that LAB supplementation reduces cholesterol content in the egg yolk [130-132], with Mikulski et al. [47] and Haddadin et al. [130] reporting a reduction of more than $10 \%$ and $18 \%$, respectively, with the addition of $P$. acidilactici and L. acidophilus. In these studies, egg yolk cholesterol content depended on the administered dose and on the bacteria used as probiotics.

Honey bees are distributed worldwide and, besides producing honey, these insects are considered one of the main crop pollinators. The products and byproducts resulting from apicultural production, such as honey and pollen, are known for their medicinal and nutritional properties, and are classified as safe, health-promoting foods [4]. Within the $\mathrm{LAB}$, the former Lactobacillus genus was the most frequently identified in the beehive, and Apilactobacillus kunkeei was predominantly isolated from honey, bee pollen, bee bread, and royal jelly. Immunomodulatory activity through secretion of $\operatorname{IgA}$ has been reported in this species [133]. In another study, a total of 43 LAB species has been identified in beehives and, of these, 20 species showed antimicrobial activity against animal and human pathogens [6]. Lactobacilli, Enterococcus, and Weissella demonstrated in vitro inhibitory effects against Paenibacillus larvae, an enthomopathogen that affects bee larvae [134]. Moreover, honey has demonstrated antimicrobial properties against a broad range of pathogenic bacteria, including Staph.aureus, Pseudomonas aeruginosa, E. coli, Bacillus cereus, and Salmonella spp. [135]. Not only the use of probiotics containing LAB species in beekeeping may contribute to prevent bee diseases and increase honey production, but also the promising antimicrobial characteristics against pathogenic microorganisms of the native LAB found in honey and other bee products can make them suitable candidates for the development of food-grade biopreservatives [6,135]. However, antibiotic resistances were also evident in some of these $L A B$, a factor that must be considered prior to their application [6].

\section{Presence of antimicrobial-resistant LAB in animal food products}

Measures have been implemented worldwide to limit inadequate use and overuse of antibiotics in animals, particularly in livestock production. The increase of antimicrobial resistance to antibiotics in animal production chains and the presence of antibiotic residues in animal products can pose serious health risks for humans, as final consumers of these products [42]. Probiotics have increasingly been applied as an alternative to antibiotics, both as animal growth-promoters and in the combat against pathogenic microorganisms. LAB with health-promoting abilities are usually classified and used as probiotics. Although the benefits of using LAB in the production of a variety of dairy and meat fermented foods are well documented, due to their contribution to the sensorial properties of these foods and to the production of antimicrobial compounds, the presence of antimicrobial resistance in LAB strains used in the food industry is not [136].

Most LAB used in animal feed or animal-derived foods occur naturally in the animals (e.g., in their gastrointestinal tract) or in the resulting products. Although LAB with probiotic potential are considered non-pathogenic, the risks associated with the possible genetic transfer of antimicrobial resistance or toxin production to pathogenic microorganisms cannot be disregarded [38,73]. Horizontal transfer of antibiotic resistance genes may occur through mobile elements (integrons, transposons, and plasmids). In some strains of the former Lactobacillus genus, the presence of antibiotic resistance genes has been reported [28]. Some LAB, beyond acquired antibiotic resistances, also show intrinsic antibiotic resistance. For example, the best characterized intrinsic resistance in 
$\mathrm{LAB}$ is that of some lactobacilli to vancomycin. The presence of intrinsic antibiotic resistance genes is undesirable, but may not constitute a safety issue, since $L A B$ are very rarely involved in infections and these genes are not easily mobilized and transferred to other pathogens [105].

Several studies on autochthonous food bacteria have highlighted the potential role of $\mathrm{LAB}$ as reservoirs of antibiotic resistance genes, from where resistance determinants could be transferred to the human microbiome via food chain [28,137-139]. For instance, in the production of dry-fermented sausages, antibiotic-resistant LAB may be introduced through contamination of the raw materials and added ingredients, fecal contamination, improper handling, environmental contamination, cross-contamination, together with the lack of processing stepts that allow the elimination of these microorganisms. The close contact among bacteria in these foods could facilitate horizontal transfer of the antibiotic resistance genes they carry to pathogenic bacteria or to other LAB during processing $[104,140]$. Horizontal transfer of resistance genes between LAB ingested with foods and from LAB to other bacteria may also take place in the consumers' gut [141].

Genetic determinants of tetracycline, vancomycin, and erythromycin resistance have been described in Enterococcus spp., Lac. lactis, and several lactobacilli from fermented meat and milk products [28,138]. The potential role of enterococci as reservoirs of antibiotic resistance genes in dairy products [140] and their particular propensity to trade these genetic determinants with other bacteria, including pathogens, is well known [142]. A recent study detected widespread resistance to several antibiotics in LAB from fermented dairy products (yogurt and a fermented dairy drink), of which several lactobacilli (L. delbrueckii subsp. bulgaricus, L. plantarum, L. paracasei, and L. acidophilus) and Strep. salivarius subsp. thermophilus. In this study, most of the strains belonging to the former Lactobacillus genus were resistant to streptomycin (84\%) and gentamycin (84\%); less frequently, these strains showed resistance to erythromycin, sulfamethoxazole, and tetracycline. Most Strep. salivarius subsp. thermophilus also harboured resistance genes to the aminoglycosides streptomycin (92\%), and gentamycin (87\%), as well as to ciprofloxacin (79\%), chloramphenicol (72\%), and erythromycin (8\%) [143]. In another study, L. plantarum isolated from raw-milk cheese showed erythromycin resistance [144]. The research on antibiotic resistance in probiotic microorganisms obtained from yogurts, yogurt-type fermented milk, and pharmaceutical products detected resistance to aztreonam, cycloserin, kanamycin, nalidixic acid, polymyxin B, and spectinomycin in all LAB strains belonging to the Streptococcus and former Lactobacillus genera, as well as in bifidobacteria [145]. Additionally, it has been demonstrated that L. delbrueckii subsp. bulgaricus and L. plantarum can sucessfully transfer the tet $M$ and tetS tetracycline resistance genes to L. monocytogenes [143].

In meat products, all strains of Lac. lactis and L. plantarum demonstrated in vitro resistance to erythromycin and some were also resistant to vancomycin, tetracycline, and chloramphenicol, as previously described [119]. Antibiotic resistance to vancomycin was also detected in LAB strains isolated from traditional salami [105]. Gevers et al. [140] analyzed $\mathrm{LAB}$ resistance to tetracycline along the process of fermented dry sausage, demonstrating the presence of resistant lactococci, lactobacilli, streptococci, and enterococci in the raw meat, but only resistant lactobacilli were persisted after fermentation. Both the tet $\mathrm{M}$ and tetS tetracycline resistance genes were found in the raw meat isolates, but tet(M), found exclusively in the lactobacilli, was the only gene detected after sausage fermentation. This study confirms that raw meat already contains a subpopulation of resistant bacteria and that the resulting fermented meat can act as a vehicle for tetracycline resistant LAB. However, Jha et al. [43] reported that probiotic use can reduce subtherapeutic antibiotic use in poultry production and mitigate public health concerns with antibiotic resistance transfer via animal products. Additionally, there is not enough evidence that antibiotic resistance genes are transferred in poultry production by probiotic supplementation [43]. Therefore, at present, the benefits of antibiotic supplementation in food producing animals seem to outweigh the potential risks associated with dissemination of antibiotic resistance genes. However, evaluating the 
resistome of $\mathrm{LAB}$ intended for food purposes is necessary to mitigate the dissemination of such genetic determinants to human communities, mediated by foods of animal origin.

\section{Implications of foodborne antibiotic-resistant LAB in human health: One Health perspective}

With the surge in human population and the rising threat of antibiotic resistances, the necessity to promote research on alternatives to antibiotics has also increased. LAB use, especially as probiotics, is becoming popular and they have, indeed, been proven useful, both for humans and animals [2,38]. LAB application in feed improves animal performance and health, preventing infections by enteric pathogens. Moreover, LAB reduce bacterial contamination through the inhibition of foodborne pathogens in animal products, enhancing the safety and quality of the end-products in the food industry. However, this does not mean that other preventive measures - such as good hygiosanitary practices and hygiene monitorisation of the raw materials - should be neglected [98]. In humans, LAB promote health and show several beneficial effects, e.g., reduction of lactose intolerance, maintenance of normal insulin level, antidiarrheal, antineoplastic, and antiinflammatory activity, among others [2]. However, there is limitted information on the risks of probiotic bacteria used in animals and, consequently, of their products, for the human consumer and the environment. The major associated risk is the possible transference of antibiotic resistance genes from probiotic LAB strains to other bacteria $[38,73]$. In addition, the risks associated with probiotics also comprise the possibilities of infection and immune hyper-stimulation in consumers of animal products containing probiotic bacteria. Albeit infrequently reported, concerns with infection and sensibilization of skin, eye, and mucous membranes in probiotic handlers, as well as environmental contamination with potentially pathogenic microorganisms or noxious compounds have been described $[38,146,147]$.

With the exception of the enterococci, LAB infections are extremely rare. However, some cases of bacteremia, endocarditis, lactobacillemia, and antibiotic resistant infections have been reported in severely immunocompromised individuals [73]. It must be taken in account that, in the light of current knowledge, LAB beneficial effects outweigh their rare harmful effects, such as the evidence that LAB may act in the food chain as reservoirs of antimicrobial resistance genes that are horizontally transmissible to other bacteria. Indeed, according to Masood et al. [2], a routine human diet should be rich in LAB. In order to safeguard public as well as environmental health, FAO considers that there is a need for better regulation and guidelines on the use of LAB probiotics [38]. It is important to detect and assess antibiotic resistance expression, as well as to evaluate the real risk of the presence of antibiotic resistance genes in LAB from animal products and in the human gastrointestinal tract, so that specific management strategies can be adopted throughout the food chain to mitigate the potential dissemination of antibiotic resistance through animal food products [104].

On the other hand, more information is required on potential non-food uses of LAB with inhibitory potential or antimicrobial activity against human and animal pathogens, that could aid in limiting medical antibiotic use. For instance, a high number of pathogens implicated in urinary tract infections have demonstrated antibiotic resistance, making the treatment of these infections more difficult. LAB demonstrated in vitro ability to inhibit uropathogens [10] and their use for this purpose could, therefore, be envisaged. Although they have been mostly used as probiotics, starter or adjunct cultures, and their bacteriocins have been exploited as food preservatives, novel and emerging applications of LAB to inhibit human pathogens as bioprotective agents and therapeutical adjuvants, or as oral vaccines, could be anticipated for the prevention and treatment of human diseases [10], thereby contributing to minimise the use of antibiotics. 


\section{Conclusions}

Animal products, in particular dairy products, are natural and major sources of LAB with several beneficial effects for humans and animals. LAB can be advantageously applied in animal production to improve animal performance, health, and productivity; in the food industry, they have demonstrated potential as biopreservatives due to their antimicrobial properties. Their consumption in animal products has been demonstrated to have beneficial effects on human health, although a residual risk of antibiotic resistance transfer through these foods exists. This review demonstrated that, under the light of the present knowledge, the beneficial effects of LAB on the human food chain outweigh their potential harmful impacts. However, further studies and a continuous monitorization effort are necessary for the safe application of LAB in animal food products and in treatment against pathogenic microorganisms, providing a thorough assessment of the possible risks associated with the dissemination of antimicrobial resistance genes and, thereby, protecting public health.

Supplementary Materials: The following are available online at www.mdpi.com/xxx/s1, Figure S1: title, Table S1: title, Video S1: title.

Author Contributions: Conceptualization, C.M.; D.C. and P.P.; Data curation, C.M., D.C, G.I. and M.L.E.D.; Writing-original draft preparation, C.M.; Writing-review and editing, M.L.E.D. and S.C.; Supervision, G.I., M.L.E.D. and P.P. All authors have read and agreed to the published version of the manuscript.

Funding: This research was funded by the R\&D Project CAREBIO2 - Comparative assessment of antimicrobial resistance in environmental biofilms through proteomics - toward innovative theranostic biomarkers, with reference NORTE-01-0145FEDER-030101 and PTDC/SAUINF/30101/2017, financed by the European Regional Development Fund (ERDF) through the Northern Regional Operational Program (NORTE 2020) and the Foundation for Science and Technology (FCT), by FCT/MCTES funding to IITAA (UIDB/00153/2020), and by the Regional Government of the Azores (M1.1.a/008/Funcionamento/2019(IITAA). This work was supported by the Associate Laboratory for Green Chemistry-LAQV, which is financed by national funds from FCT/MCTES (UIDB/50006/2020). S. Câmara received a POST-DOC grant from Regional Fund for Science and Technology, Azores, Portugal -M.3.2.DOCPROF/F/044/2020.

Conflicts of Interest: The authors declare no conflict of interest. The funders had no role in the design of the study; in the collection, analyses, or interpretation of data; in the writing of the manuscript, or in the decision to publish the results.

\section{References}

1. Khalid, K. An overview of lactic acid bacteria. Int J Biosci 2011, 1, 1-13.

2. Masood, M.I.; Qadir, M.I.; Shirazi, J.H.; Khan, I.U. Beneficial effects of lactic acid bacteria on human beings. Crit Rev Microbiol 2011, 37, 91-8. doi: 10.3109/1040841X.2010.536522.

3. Morelli, L.; von Wright, A. Chapter 2. Genetics of Lactic Acid Bacteria. In Lactic Acid Bacteria. Microbiological and Functional Aspects; Vinderola, G.; Ouwenhand, A.; Salminen, S.; von Wright, A., Eds.; Publisher: CRC Press, Florida, USA, 2019 , pp. 17-32.

4. Sauer, M.; Russmayer, H.; Grabherr, R.; Peterbauer, CK.; Marx, H. The efficient clade: lactic acid bacteria for industrial chemical production. Trends Biotechnol 2017, 35, 756-769. doi: 10.1016/j.tibtech.2017.05.002.

5. Hayek, S.A.; Ibrahim, S.A. Current limitations and challenges with lactic acid bacteria: a review. Food Nutr Sci $2013,4,73-87$.

6. Ramos, O.Y.; Basualdo, M.; Libonatti, C.; Veja, M.F. Current status and application of lactic acid bacteria in animal production systems with a focus on bacteria from honey bee colonies. J Appl Microbiol 2020, 128, 1248-1260. doi: 10.1111/jam.14469.

7. Tian, F. Introduction. In Lactic Acid Bacteria; Chen W., Ed.; Springer, Singapore, 2019, https://doi.org/10.1007/978-981-13-7832$4 \_1$.

8. Zheng, J.; Wittouck, S.; Salvetti, E.; Franz, C.M.A.P.; Harris, H.M.B.; Mattarelli, P., O'Toole, P.W.; Pot, B.; Vandamme, P.; Walter, J.; Watanabe, K.; Wuyts, S.; Felis, G.E.; Gänzle, M.G.; Lebeer, S. A taxonomic note on the genus Lactobacillus: Description of 23 novel genera, emended description of the genus Lactobacillus Beijerinck 1901, and union of Lactobacillaceae and Leuconostocaceae. Int J Syst Evol Microbiol 2020, 70, 2782-2858. doi: 10.1099/ijsem.0.004107.

9. Liu, W.; Pang, H.; Zhang, H.; Cai Y. Biodiversity of Lactic Acid Bacteria. In Zhang, H.; Cai Y., Eds. Lactic Acid Bacteria. Publisher: Springer, Dordrecht, 2014. doi: 10.1007/978-94-017-8841-0_2. 
10. Mokoena, M.P. Lactic acid bacteria and their bacteriocins: classification, biosynthesis and applications against uropathogens: a mini-review. Molecules 2017, 22, 1255. doi: 10.3390/molecules22081255.

11. Rakhmanova, A.; Khan, Z.A.; Shah, K. A mini review fermentation and preservation: role of lactic acid bacteria. MOJ Food Process Technol 2018, 6, 414-417. doi: 10.15406/mojfpt.2018.06.00197.

12. Bengoa, A.A.; Iraporda, C.; Garrote, G.L.; Abraham, A.G. Kefir micro-organisms: their role in grain assembly and health properties of fermented milk. J Appl Microbiol, 2019, 126, 686-700. doi: 10.1111/jam.14107.

13. García-Ruiz, A.; Moreno-Arribas, M.V.; Martín-Álvarez, P.J.; Bartolomé, B. Comparative study of the inhibitory effects of wine polyphenols on the growth of enological lactic acid bacteria. Int J Food Microbiol 2011, 145, 426-31. doi: 10.1016/j.ijfoodmicro.2011.01.016.

14. Portilha-Cunha, M.F.; Macedo, A.C.; Malcata, F.X. A review on adventitious lactic acid bacteria from table olives. Foods 2020, 9 , 948. doi: 10.3390/foods9070948.

15. Ashaolu, T.J.; Reale, A. A holistic review on Euro-Asian lactic acid bacteria fermented cereals and vegetables. Microorganisms 2020, 8, 1176. doi: 10.3390/microorganisms8081176.

16. Pereira, G.V.M.; Neto, D.P.C.; Junqueira, A.C.O.; Karp, S.G.; Letti, L.A.J.; Magalhães Júnior, A.I.; Soccol, C.R. A Review of Selection Criteria for Starter Culture Development in the Food Fermentation Industry, Food Rev Int 2020, 36, 135-167. doi: 10.1080/87559129.2019.1630636

17. Gao, Z.; Daliri, E.B.; Wang, J.; Liu, D.; Chen, S.; Ye, X.; Ding, T. Inhibitory effect of lactic acid bacteria on foodborne pathogens: a review. J Food Prot 2019, 82, 441-453. doi: 10.4315/0362-028X.JFP-18-303.

18. Varsha, K.K.; Nampoothiri, K.M. Appraisal of lactic acid bacteria as protective cultures. Food Control 2016, 69: 61-64. doi: 10.1016/j.foodcont.2016.04.032.

19. Zagorec, M.; Champomier-Vergès, M.C. Lactobacillus sakei: a starter for sausage fermentation, a protective culture for meat products. Microorganisms 2017, 5, 56. doi: 10.3390/microorganisms5030056.

20. Delcarlo, S.B.; Parada, R.; Schelegueda, L.I.; Vallejo, M.; Marguet, E.R.; Campos, C.A. From the isolation of bacteriocinogenic LAB strains to the application for fish paste biopreservation. LWT 2019, 110, 239-246. doi: 10.1016/j.lwt.2019.04.079.

21. Ghanbari, M.; Jami, M.; Domig, K.J.; Kneifel, W. Seafood biopreservation by lactic acid bacteria - a review. LWT, 2013, 54, 315324. doi: 10.1016/j.lwt.2013.05.039.

22. Arena, M.P., Capozzi, V., Russo, P., Drider, D., Spano, G., Fiocco, D. Immunobiosis and probiosis: antimicrobial activity of lactic acid bacteria with a focus on their antiviral and antifungal properties. Appl Microbiol Biotechnol 2018, 102, 9949-9958. doi: 10.1007/s00253-018-9403-9.

23. Saez-Lara, M.J.; Gomez-Llorente, C.; Plaza-Diaz, J.; Gil, A. The role of probiotic lactic acid bacteria and bifidobacteria in the prevention and treatment of inflammatory bowel disease and other related diseases: a systematic review of randomized human clinical trials. Biomed Res Int 2015, 2015, 505878. doi: 10.1155/2015/505878.

24. De Filippis, F.; Pasolli, E.; Ercolini, D. The food-gut axis: lactic acid bacteria and their link to food, the gut microbiome and human health. FEMS Microbiol Rev 2020, 44, 454-489. doi: 10.1093/femsre/fuaa015.

25. Stiemsma, L.T.; Nakamura, R.E.; Nguyen, J.G.; Michels, K.B. Does consumption of fermented foods modify the human gut microbiota? J Nutr 2020, 150, 1680-1692. doi: 10.1093/jn/nxaa077.

26. Varzakas, T. Microbiology of fermented foods and beverages. Foods 2020, 9, 1660. doi: 10.3390/foods9111660.

27. Cui, Y., Miao, K., Niyaphorn, S., Qu, X. Production of gamma-aminobutyric acid from lactic acid bacteria: a systematic review. Int J Mol Sci 2020, 3, 995. doi: 10.3390/ijms21030995.

28. Mathur, S.; Singh, R. Antibiotic resistance in food lactic acid bacteria - a review. Int J Food Microbiol 2005, 105, 281-295. doi: 10.1016/j.ijfoodmicro.2005.03.008.

29. Hudson, J.; Frewer, L.J.; Jones, G.; Brerenton, P.A.; Whittingham, M.J.; Stewart, G. The agri-food chain and antimicrobial resistance: a review. Trends Food Sci Technol 2017, 69A, 131-147. 10.1016/j.tifs.2017.09.007.

30. Oliveira, A.S.; Weinberg, Z.G.; Ogunade, I.M.; Cervantes, A.A.P.; Arriola, K.G.; Jiang, Y.; Kim, D.; Li, X.; Gonçalves, M.C.M.; Vyas, D.; Adesogan, A.T. Meta-analysis of effects of inoculation with homofermentative and facultative heterofermentative lactic acid bacteria on silage fermentation, aerobic stability, and the performance of dairy cows. J Dairy Sci 2017, 100, 4587-4603. doi: 10.3168/jds.2016-11815.

31. Muck, R.E.; Nadeau, E.M.G.; McAllister, T.A.; Contreras-Govea, F.E.; Santos, M.C.; Kung, L.Jr. Silage review: Recent advances and future uses of silage additives. J Dairy Sci 2018, 101, 3980-4000. doi: 10.3168/jds.2017-13839.

32. Libonatti, C.; Agüeria, D.; García, C.; Basualdo, M. Weissella paramesenteroides encapsulation and its application in the use of fish waste. Rev Argent Microbiol 2019, 51, 81-83. doi: 10.1016/j.ram.2018.03.001.

33. Yeoman, C.J.; White, B.A. Gastrointestinal tract microbiota and probiotics in production animals. Annu Rev Anim Biosci 2014, 2, 469-86. doi: 10.1146/annurev-animal-022513-114149. 
34. Kazemi, S.A.; Ahmadi, H.; Karimi Torshizi, M.A. Evaluating two multistrain probiotics on growth performance, intestinal morphology, lipid oxidation and ileal microflora in chickens. J Anim Physiol Anim Nutr (Berl) 2019, 103, 1399-1407. doi: 10.1111/jpn.13124.

35. Dowarah, R.; Verma, A.K.; Agarwal, N.; Singh, P.; Singh, B.R. Selection and characterization of probiotic lactic acid bacteria and its impact on growth, nutrient digestibility, health and antioxidant status in weaned piglets. PLoS One 2018, 13, e0192978. doi: 10.1371/journal.pone.0192978.

36. Dowarah, R.; Verma, A.K.; Agarwal, N.; Singh, P. Efficacy of species-specific probiotic Pediococcus acidilactici FT28 on blood biochemical profile, carcass traits and physicochemical properties of meat in fattening pigs. Res Vet Sci 2018, 117, 60-64. doi: 10.1016/j.rvsc.2017.11.011.

37. Joysowal, M.; Saikia, B.N.; Dowarah, R.; Tamuly, S.; Kalita, D.; Choudhury, K.B.D. Effect of probiotic Pediococcus acidilactici FT28 on growth performance, nutrient digestibility, health status, meat quality, and intestinal morphology in growing pigs. Vet World 2018, 11, 1669-1676. doi: 10.14202/vetworld.2018.1669-1676.

38. FAO. Probiotics in animal nutrition - Production, impact and regulation, by Yadav S. Bajagai, Athol V. Klieve, Peter J. Dart and Wayne L. Bryden. Editor Harinder P.S. Makkar. FAO Animal Production and Health Paper No. 179. Rome, Italy, 2016.

39. Frizzo, L.; Zbrun, M.; Soto, L.; Signorini, M. Effects of probiotics on growth performance in young calves: A meta-analysis of randomized controlled trials. Animal Feed Sci Technol 2011, 169, 147-156. doi: 10.1016/j.anifeedsci.2011.06.009.

40. Signorini, M.L.; Soto, L.P.; Zbrun, M.V.; Sequeira, G.J.; Rosmini, M.R.; Frizzo, L.S. Impact of probiotic administration on the health and fecal microbiota of young calves: a meta-analysis of randomized controlled trials of lactic acid bacteria. Res Vet Sci 2012, 93, 250-258. doi: 10.1016/j.rvsc.2011.05.001.

41. Doyle, N.; Mbandlwa, P.; Kelly, W.J.; Attwood, G.; Li, Y.; Ross, R.P.; Stanton, C.; Leahy S. Use of lactic acid bacteria to reduce methane production in ruminants, a critical review. Front Microbiol 2019, 10, 2207. doi: 10.3389/fmicb.2019.02207.

42. Jin, L.Z.; Ho, Y.W.; Abdullah, N.; Jalaludin, S. Growth performance, intestinal microbial populations, and serum cholesterol of broilers fed diets containing Lactobacillus cultures. Poult Sci 1998, 77, 1259-1265. doi: 10.1093/ps/77.9.1259.

43. Jha, R.; Das, R.; Oak, S.; Mishra, P. Probiotics (direct-fed microbials) in poultry nutrition and their effects on nutrient utilization, growth and laying performance, and gut health: a systematic review. Animals (Basel) 2020, 10, 1863. doi: 10.3390/ani10101863.

44. Noohi, N.; Ebrahimipour, G.; Rohani, M.; Talebi, M.; Pourshafie, M.R. Evaluation of potential probiotic characteristics and antibacterial effects of strains of Pediococcus species isolated from broiler chickens. Br Poult Sci 2016, 57, 317-323. doi: 10.1080/00071668.2016.1169247.

45. Feng, J.; Wang, L.; Zhou, L.; Yang, X.; Zhao, X. Using in vitro immunomodulatory properties of lactic acid bacteria for selection of probiotics against Salmonella infection in broiler chicks. PLoS One 2016, 11, e0147630. doi: 10.1371/journal.pone.0147630.

46. Vásquez, A.; Forsgren, E.; Fries, I.; Paxton, R.J.; Flaberg, E.; Szekely, L.; Olofsson, T.C. Symbionts as major modulators of insect health: lactic acid bacteria and honeybees. PLoS One 2012, 7, e33188. doi: 10.1371/journal.pone.0033188.

47. Mikulski, D.; Jankowski, J.; Naczmanski, J.; Mikulska, M.; Demey, V. Effects of dietary probiotic (Pediococcus acidilactici) supplementation on performance, nutrient digestibility, egg traits, egg yolk cholesterol, and fatty acid profile in laying hens. Poult Sci 2012, 91, 2691-2700. doi: 10.3382/ps.2012-02370.

48. Dimidi, E.; Cox, S.R.; Rossi, M.; Whelan, K. Fermented Foods: Definitions and Characteristics, Impact on the Gut Microbiota and Effects on Gastrointestinal Health and Disease. Nutrients 2019, 11, 1806. doi: 10.3390/nu11081806.

49. Marco, M.L.; Heeney, D.; Binda, S.; Cifelli, C.J.; Cotter, P.D.; Foligné, B.; Gänzle, M.; Kort, R.; Pasin, G.; Pihlanto, A.; Smid, E.J.; Hutkins, R. Health benefits of fermented foods: microbiota and beyond. Curr Opin Biotechnol 2017, 44, 94-102. doi: 10.1016/j.copbio.2016.11.010.

50. Bachtarzi, N.; Kharroub, K.; Ruas-Madiedo, P. Exopolysaccharide-producing lactic acid bacteria isolated from traditional Algerian dairy products and their application for skim-milk fermentations. LWT 2019, 107, 117-124. doi: 10.1016/j.lwt.2019.03.005.

51. Dapkevicius, M.L.N.E.; Nout, M.J.R.; Rombouts, F.M.; Houben, J.H.; Wymenga, W. Biogenic amine formation and degradation by potential fish silage starter microorganisms. Int J of Food Microbiol 2000, 57, 1107-1114. doi: 10.1016/S0168-1605(00)00238-5.

52. Nebbia, S.; Lamberti, C.; Lo Bianco, G.; Cirrincione, S.; Laroute, V.; Cocaign-Bousquet, M.; Cavallarin, L.; Giuffrida, M.G.; Pessione, E. Antimicrobial potential of food lactic acid bacteria: bioactive peptide decrypting from caseins and bacteriocin production. Microorganisms 2021, 9, 65. doi: 10.3390/microorganisms9010065.

53. Lynch, K.M.; Zannini, E.; Coffey, A.; Arendt, E.K. Lactic acid bacteria exopolysaccharides in foods and beverages: isolation, properties, characterization, and health benefits. Annu Rev Food Sci Technol 2018, 25, 155-176. doi: 10.1146/annurev-food-030117012537.

54. Kieliszek, M.; Pobiega, K.; Piwowarek, K.; Kot, A.M. Characteristics of the proteolytic enzymes produced by lactic acid bacteria. Molecules 2021, 26,1858. doi: 10.3390/molecules26071858.

55. Favaro, L.; Todorov, S.D. Bacteriocinogenic LAB strains for fermented meat preservation: perspectives, challenges, and limitations. Probiotics Antimicrob Proteins 2017, 9, 444-458. doi: 10.1007/s12602-017-9330-6. 
56. Scatassa, M. L.; Gaglio, R.; Cardamone, C.; Macaluso, G.; Arcuri, L.; Todaro, M.; Mancuso, I. Anti-listeria activity of lactic acid bacteria in two traditional Sicilian cheeses. Ital J Food Saf 2017, 6, 6191. doi: 10.4081/ijfs.2017.6191.

57. Vieco-Saiz, N.; Belguesmia, Y.; Raspoet, R.; Auclair, E.; Gancel, F.; Kempf, I.; Drider, D. Benefits and inputs from lactic acid bacteria and their bacteriocins as alternatives to antibiotic growth promoters during food-animal production. Front Microbiol 2019, 10, 57. doi: 10.3389/fmicb.2019.00057.

58. Brown, L.; Pingitore, E.V.; Mozzi, F.; Saavedra, L.; Villegas, J.M.; Hebert, E.M. Lactic acid bacteria as cell factories for the generation of bioactive peptides. Protein Pept Lett 2017, 24,146-155. doi: 10.2174/0929866524666161123111333.

59. Hernández-González, J.C.; Martínez-Tapia, A.; Lazcano-Hernández, G.; García-Pérez, B.E., Castrejón-Jiménez, N.S. Bacteriocins from lactic acid bacteria. A powerful alternative as antimicrobials, probiotics, and immunomodulators in veterinary medicine. Animals (Basel) 2021, 11, 979. doi: 10.3390/ani11040979.

60. Manna, S.; Chowdhury, T.; Chakraborty, R.; Mandal, S.M. Probiotics-derived peptides and their immunomodulatory molecules can play a preventive role against viral diseases including COVID-19. Probiotics Antimicrob Proteins 2021, 13, 611-623. doi: 10.1007/s12602-020-09727-7.

61. Reyes-Díaz, A.; González-Córdova, A.F.; Hernández-Mendoza, A.; Reyes-Díaz, R.; Vallejo-Cordoba, B. Immunomodulation by hydrolysates and peptides derived from milk proteins. Int J Dairy Technol 2017, 71, 1-9. doi: 10.1111/1471-0307.12421.

62. Lorenzo, J.M.; Munekata, P.E.S.; Gómez, B.; Barba, F.J.; Mora, L.; Pérez-Santaescolástica, C.; Toldrá, F. Bioactive peptides as natural antioxidants in food products - a review. Trends Food Sci Technol 2018, 79, 136-147. doi: 10.1016/j.tifs.2018.07.003.

63. Barbieri, F.; Montanari, C.; Gardini, F.; Tabanelli, G. Biogenic amine production by lactic acid bacteria: a review. Foods 2019, 8, 17. doi:10.3390/foods8010017.

64. Naila, A.; Flint, S.; Fletcher, G.; Bremer, P.; Meerdink, G. Control of biogenic amines in food - existing and emerging approaches. J Food Sci 2010, 75, R139-150. doi: 10.1111/j.1750-3841.2010.01774.x.

65. Hill, D.; Sugrue, I.; Arendt, E.; Hill, C.; Stanton, C.; Ross, R.P. Recent advances in microbial fermentation for dairy and health. F1000Res 2017, 6, 751. doi: 10.12688/f1000research.

66. Leroy, F.; De Vuyst, L. Lactic acid bacteria as functional starter cultures for the food fermentation industry. Trends in Food Sci Technol 2004, 15, 67-78.

67. Dapkevicius, M.d.L.E.; Sgardioli, B.; Câmara, S.P.A.; Poeta, P.; Malcata, F.X. Current trends of enterococci in dairy products: a comprehensive review of their multiple roles. Foods 2021, 10, 821. doi: 10.3390/foods10040821.

68. Graham, K.; Stack, H.; Rea, R. Safety, beneficial and technological properties of enterococci for use in functional food applications - a review. Crit Rev Food Sci Nutr 2020, 60, 3836-3861. doi: 10.1080/10408398.2019.1709800.

69. Douillard, F.P.; de Vos W.M. Functional genomics of lactic acid bacteria: from food to health. Microb Cell Fact 2014, 13 Suppl 1, S8. doi: 10.1186/1475-2859-13-S1-S8.

70. Makarova, K.; Slesarev, A.; Wolf, Y.; Sorokin, A.; Mirkin, B.; Koonin, E.; Pavlov, A.; Pavlova, N.; Karamychev, V.; Polouchine, N.; Shakhova, V.; Grigoriev, I.; Lou, Y.; Rohksar, D.; Lucas, S.; Huang, K.; Goodstein, D.M.; Hawkins, T.; Plengvidhya, V.; Welker, D.; Hughes, J.; Goh, Y.; Benson, A.; Baldwin, K.; Lee, J.H.: Díaz-Muñiz, I.; Dosti, B.; Smeianov, V.; Wechter, W.; Barabote, R.; Lorca, G.; Altermann, E.; Barrangou, R.; Ganesan, B.; Xie, Y.; Rawsthorne, H.; Tamir, D.; Parker, C.; Breidt, F.; Broadbent, J.; Hutkins, R.; O'Sullivan, D.; Steele, J.; Unlu, G.; Saier, M.; Klaenhammer, T.; Richardson, P.; Kozyavkin, S.; Weimer, B.; Mills, D. Comparative genomics of the lactic acid bacteria. Proc Natl Acad Sci USA 2006, 103, 15611-15616. doi: 10.1073/pnas.0607117103.

71. George, F.; Daniel, C.; Thomas, M.; Singer, E.; Guilbaud, A.; Tessier, F.J.; Revol-Junelles, A.M.; Borges, F.; Foligné, B. Occurrence and dynamism of lactic acid bacteria in distinct ecological niches: a multifaceted functional health perspective. Front Microbiol 2018, 9, 2899. doi: 10.3389/fmicb.2018.02899.

72. Terzić-Vidojević, A.; Veljović, K.; Tolinački, M.; Živković, M.; Lukić, J.; Lozo, J.; Fira, Đ.; Jovčić, B.; Strahinić, I.; Begović, J.; Popović, N.; Miljković, M.; Kojić, M.; Topisirović, L.; Golić, N. Diversity of non-starter lactic acid bacteria in autochthonous dairy products from Western Balkan Countries - Technological and probiotic properties. Food Res Int 2020, 136, 109494. doi: 10.1016/j.foodres.2020.109494.

73. Bernardeau, M.; Vernoux, J.P.; Henri-Dubernet, S.; Guéguen, M. Safety assessment of dairy microorganisms: the Lactobacillus genus. Int J Food Microbiol 2008, 126, 278-285. doi: 10.1016/j.ijfoodmicro.2007.08.015.

74. Tilocca, B.; Costanzo, N.; Morittu, V.M.; Spina, A.A.; Soggiu, A.; Britti, D.; Roncada, P.; Piras, C. Milk microbiota: characterization methods and role in cheese production. J Proteomics 2020, 210, 103534. doi: 10.1016/j.jprot.2019.

75. Riquelme, C.; Câmara, S.; Dapkevicius, M. L.; Vinuesa, P.; Silva, C.C.; Malcata, F.X.; Rego, O.A. Characterization of the bacterial biodiversity in Pico cheese (an artisanal Azorean food). Int J Food Microbiol 2015, 192, 86-94. doi: 10.1016/j.ijfoodmicro.2014.09.031.

76. Poznanski, E.; Cavazza, A.; Cappa, F.; Cocconcelli, P.S. Indigenous raw milk microbiota influences the bacterial development in traditional cheese from an alpine natural park. Int J Food Microbiol 2004, 92, 141-51. doi: 10.1016/j.ijfoodmicro.2003.09.006. 
77. Montel, M.C.; Buchin, S.; Mallet, A.; Delbès-Paus, C.; Vuitton, D.A.; Desmasures, N.; Berthier, F. Traditional cheeses: rich and diverse microbiota with associated benefits. Int J Food Microbiol 2014, 177, 136-154. doi: 10.1016/j.ijfoodmicro.2014.02.019.

78. Casalta, E.; Montel, M.C. Safety assessment of dairy microorganisms: the Lactococcus genus. Int J Food Microbiol, 2008, 126, 271273. doi: 10.1016/j.ijfoodmicro.2007.08.013.

79. Song, A.A.; In, L.L.A.; Lim, S.H.E.; Rahim, R.A. A review on Lactococcus lactis: from food to factory. Microb Cell Fact 2017, 16, 55. doi: 10.1186/s12934-017-0669-x.

80. Ouwenhand, A.C.; Kirjavainen, P.V.; Shortt, C.; Salminen S. Probiotics: mechanisms and established effects. Int Dairy J 1999, 9 , 43-52. doi: 10.1016/S0958-6946(99)00043-6.

81. Bourdichon, F.; Casaregola, S.; Farrokh, C.; Frisvad, J.C.; Gerds, M.L.; Hammes, W.P.; Harnett, J.; Huys, G.; Laulund, S.; Ouwehand, A.; Powell, I.B.; Prajapati, J.B.; Seto, Y.; Ter Schure, E.; Van Boven, A.; Vankerckhoven, V.; Zgoda, A.; Tuijtelaars, S.; Hansen, E.B. Food fermentations: microorganisms with technological beneficial use. Int J Food Microbiol 2012,154, 87-97. doi: 10.1016/j.ijfoodmicro.2011.12.030.

82. Mills, S.; O'Suillvan, O.; Hill, C.; Fitzgerald, G.; Ross, R.P. The changing face of dairy starter culture research: from genomics to economics. Int J Dairy Technol 2010, 63, 149e170. doi: 10.1111/j.1471-0307.2010.00563.x.

83. Câmara, S.P.; Dapkevicius, A.; Riquelme, C.; Elias, R.B.; Silva, C.; Malcata, F.X.; Dapkevicius, M. Potential of lactic acid bacteria from Pico cheese for starter culture development. Food Sci Technol Int 2019, 25, 303-317. doi: 10.1177/1082013218823129

84. Freitas, C.; Malcata, F.X. Microbiology and biochemistry of cheeses with Appélation d'Origine Protegée and manufactured in the Iberian Peninsula from ovine and caprine milks. J Dairy Sci 2000, 83, 584-602. doi: 10.3168/jds.s0022-0302(00)74918-6.

85. Domingos-Lopes, M.F.P.; Lamosa, P.; Stanton, C.; Ross, R.P.; Silva, C.C.G. Isolation and characterization of an exopolysaccharide-producing Leuconostoc citreum strain from artisanal cheese. Lett Appl Microbiol 2018, 67, 570-578. doi: 10.1111/lam.13073.

86. Silva, C.C.; Domingos-Lopes, M.F.; Magalhães, V.A.; Freitas, D.A.; Coelho, M.C.; Rosa, H.J.; Dapkevicius, M.L. Short communication: Latin-style fresh cheese enhances lactic acid bacteria survival but not Listeria monocytogenes resistance under in vitro simulated gastrointestinal conditions. J Dairy Sci 2015, 98, 4377-4383. doi: 10.3168/jds.2015-9420.

87. Kongo, J.M.; Ho, A.J.; Malcata, F.X.; Wiedmann, M. Characterization of dominant lactic acid bacteria isolated from São Jorge cheese, using biochemical and ribotyping methods. J Appl Microbiol 2007, 103, 1838-44. doi: 10.1111/j.1365-2672.2007.03423.x.

88. Pino, A.; Russo, N.; Van Hoorde, K.; De Angelis, M.; Sferrazzo, G.; Randazzo, C.L.; Caggia, C. Piacentinu Ennese PDO cheese as reservoir of promising probiotic bacteria. Microorganisms 2019, 7, 254. doi: 10.3390/microorganisms7080254.

89. Stefanovic, E.; Fitzgerald, G.; McAuliffe, O. Advances in the genomics and metabolomics of dairy lactobacilli: a review. Food Microbiol 2017, 61, 33-49. doi: 10.1016/j.fm.2016.08.009.

90. EFSA BIOHAZ Panel (EFSA Panel on Biological Hazards). Koutsoumanis, K.; Allende, A.; Alvarez-Ordóñez, A.; Bolton, D.; Bover-Cid, S.; Chemaly, M.; Davies, R.; De Cesare, A.; Hilbert, F.; Lindqvist, R.; Nauta, M.; Peixe, L.; Ru, G.; Simmons, M.; Skandamis, P.; Suffredini, E.; Cocconcelli, P.S.; Fernández Escámez, P.S.; Maradona, M.P.; Querol, A.; Suarez, J.E.; Sundh, I.; Vlak, J.; Barizzone, F.; Hempen, M.; Herman, L. Statement on the update of the list of QPS-recommended biological agents intentionally added to food or feed as notified to EFSA 12: suitability of taxonomic units notified to EFSA until March 2020. EFSA J 2020, 18, 6174. doi: 10.2903/j.efsa.2020.6174.

91. Hemme, D.; Foucaud-Scheunemann, C. Leuconostoc, characteristics, use in dairy technology and prospects in functional foods. Int Dairy J 2004, 14, 467-494. doi: 10.1016/j.idairyj.2003.10.005.

92. Firmesse, O.; Alvaro, E.; Mogenet, A.; Bresson, J-L.; Lemée, R.; Le Ruyet, P.; Bonhomme, C.; Lambert, D.; Andrieux, C.; Doré, J.; Corthier, G.; Furet, J.P.; Rigottier-Gois, L. Fate and effects of Camembert cheese micro-organisms in the human colonic microbiota of healthy volunteers after regular Camembert consumption. Int J Food Microbiol 2008, 125, 176-81. doi: 10.1016/j.ijfoodmicro.2008.03.044.

93. Casey, M.G.; Häni, J.P.; Gruskovnjak, J.; Schaeren, W.; Wechsler, D. Characterisation of the non-starter lactic acid bacteria (NSLAB) of Gruyère PDO cheese. Lait 2006, 86, 407-414. doi: 10.1051/lait:2006020.

94. Hanchi, H.; Mottawea, W.; Sebei, K.; Hammami, R. The genus Enterococcus: between probiotic potential and safety concerns an update. Front Microbiol 2018, 9, 1791. doi: 10.3389/fmicb.2018.01791.

95. Pacini, F.; Cariolato, D.; Andrighetto, C.; Lombardi, A. Occurrence of Streptococcus macedonicus in Italian cheeses. FEMS Microbiol Lett 2006, 261, 69-73. doi: 10.1111/j.1574-6968.2006.00330.x.

96. Gobbetti, M.; Calasso, M. Streptococcus - introduction. In Encyclopedia of Food Microbiology, 2nd ed.; Batt, C. A.; Tortorello, M.L. Eds.; Publisher: Academic Press, 2014, pp. 535-553. doi: 10.1016/B978-0-12-384730-0.00324-4.

97. Arqués, J.L.; Rodríguez, E.; Langa, S.; Landete, J.M.; Medina, M. Antimicrobial activity of lactic acid bacteria in dairy products and gut: effect on pathogens. Biomed Res Int 2015, 2015, 584183. doi: 10.1155/2015/584183.

98. Harris, L.J.; Flemming, H.P.; Klaenhammer, T.R. Sensitivity and resistance of Listeria monocytogenes ATCC 19115, Scott A and UAL 500 to nisin. J Food Protection 2001, 54, 836-840. 
99. Siedler, S.; Rau, M.H.; Bidstrup, S.; Vento, J.M.; Aunsbjerg, S.D.; Bosma, E.F.; McNair, L.M.; Beisel, C.L.; Neves, A.R. Competitive exclusion is a major bioprotective mechanism of lactobacilli against fungal spoilage in fermented milk products. Appl Environ Microbiol 2020, 86, e02312-19. doi: 10.1128/AEM.02312-19.

100. Pisacane, V.; Callegari, M.L.; Puglisi, E.; Dallolio, G.; Rebecchi, A. Microbial analyses of traditional Italian salami reveal microorganisms transfer from the natural casing to the meat matrix. Int J Food Microbiol 2015, 207, 57-65. doi: 10.1016/j.ijfoodmicro.2015.04.029.

101. Greppi, A.; Ferrocino, I.; La Storia, A.; Rantsiou, K.; Ercolini, D.; Cocolin L. Monitoring of the microbiota of fermented sausages by culture independent rRNA-based approaches. Int J Food Microbiol 2015, 212, 67-75. doi: 10.1016/j.ijfoodmicro.2015.01.016.

102. Maksimovic, A.Z.; Zunabovic-Pichler, M.; Mayrhofer, S.; Hulak, N.; Domig, K.J.; Fuka, M.M. Microbiological hazards and potential of spontaneously fermented game meat sausages: a focus on lactic acid bacteria diversity. LWT 2018, 89, 418-426. doi: 10.1016/j.lwt.2017.11.017.

103. Fadda, S.; López, C.; Vignolo, G. Role of lactic acid bacteria during meat conditioning and fermentation: peptides generated as sensorial and hygienic biomarkers. Meat Sci 2010, 86, 66-79. doi: 10.1016/j.meatsci.2010.04.023.

104. Fraqueza, M.J. Antibiotic resistance of lactic acid bacteria isolated from dry-fermented sausages. Int J Food Microbiol 2015, 212, 76-88. doi: 10.1016/j.ijfoodmicro.2015.04.035.

105. Todorov, S.D.; Stojanovski, S.; Iliev, I.; Moncheva, P.; Nero, L.A.; Ivanova, I.V. Technology and safety assessment for lactic acid bacteria isolated from traditional Bulgarian fermented meat product "lukanka". Braz J Microbiol 2017, 48, 576-586. doi: 10.1016/j.bjm.2017.02.005.

106. Leroy, F.; Verluyten, J.; de Vuyst, L. Functional meat starter cultures for improved sausages fermentation. Int J FoodMicrobiol 2006, 106, 270-285. doi: 10.1016/j.ijfoodmicro.2005.06.027.

107. Capita, R.; Llorente-Marigomez, S.; Prieto, M.; Alonso-Calleja, C. Microbiological profiles, $\mathrm{pH}$ and titratable acidity of chorizo and salchichón (two Spanish dry fermented sausages) manufactured with ostrich, deer, or pork meat. J Food Protect 2006, 69, 1183-1189. doi: 10.4315/0362-028x-69.5.1183.

108. Bromberg, R.; Moreno, I.; Zagnanini, C.L.; Delboni, R.R.; Oliveira, J. Isolation of bacteriocin producing lactic acid bacteria from meat and meat products and its spectrum of inhibitory activity. Braz J Microbiol 2004, 35, 137-144. doi: 10.1590/S151783822004000100023.

109. Jairath, G.; Singh, P.K.; Dabur, R.S.; Rani, M.; Chaudhari M. Biogenic amines in meat and meat products and its public health significance: a review. J Food Sci Technol 2015, 52, 6835-6846. doi: 10.1007/s13197-015-1860-x.

110. Zhang, Q.; Song, X.; Sun, W.; Wang, C.; Li, C.; He, L.; Wang, X.; Tao, H.; Zeng, X. Evaluation and application of different cholesterol-lowering lactic acid bacteria as potential meat starters. J Food Prot 2021, 84, 63-72. doi: 10.4315/JFP-20-225.

111. Shao, X.; Xu, B.; Chen, C.; Li, P.; Luo, H. The function and mechanism of lactic acid bacteria in the reduction of toxic substances in food: a review. Crit Rev Food Sci Nutr 2021, 8, 1-14. doi: 10.1080/10408398.2021.1895059

112. Shoukat, S. Potential anti-carcinogenic effect of probiotic and lactic acid bacteria in detoxification of benzo[a]pyrene: a review. Trends Food Sci Technol 2020, 99, 450-459. doi: 10.1016/j.tifs.2020.02.029.

113. Kostrzynska, M.; Bachand, A. Use of microbial antagonism to reduce pathogen levels on produce and meat products: a review. Can J Microbiol 2006, 52, 1017-1026. doi: 10.1139/w06-058.

114. Castellano, P.; Pérez Ibarreche, M.; Blanco Massani, M.; Fontana, C.; Vignolo, G.M. Strategies for pathogen biocontrol using lactic acid bacteria and their metabolites: a focus on meat ecosystems and industrial environments. Microorganisms 2017, 5, 38. doi: 10.3390/microorganisms5030038.

115. Leroy, F.; Scholliers, P.; Amilien, V. Elements of innovation and tradition in meat fermentation: conflicts and synergies. Int $J$ Food Microbiol 2015, 212, 2-8. doi: 10.1016/j.ijfoodmicro.2014.11.016.

116. Kołożyn-Krajewska, D.; Dolatowski, Z.J. Probiotic meat products and human nutrition. Process Biochem 2012, 47, 1761-1772. doi: 10.1016/j.procbio.2012.09.017.

117. Cavalheiro, C.P.; Ruiz-Capillas, C.; Herrero, A.M.; Jiménez-Colmenero, F.; Menezes, C.R.; Fries, L.L.M. Application of probiotic delivery systems in meat products. Trends Food Sci Technol 2015, 46, 120-131. doi: 10.1016/j.tifs.2015.09.004.

118. Pothakos, V.; Devlieghere, F.; Villani, F.; Björkroth, J.; Ercolini, D. Lactic acid bacteria and their controversial role in fresh meat spoilage. Meat Sci 2015, 109, 66-74. doi: 10.1016/j.meatsci.2015.04.014.

119. Moreno, I.; Marasca, E.T.G.; de Sá, P.B.Z.R.; de Souza Moitinho, J.; Marquezini, M.G.; Alves, M.R.C.; Bromberg, R. Evaluation of probiotic potential of bacteriocinogenic lactic acid bacteria strains isolated from meat products. Probiotics Antimicrob Proteins 2018, 10, 762-774. doi: 10.1007/s12602-018-9388-9.

120. Ringø, E.; Hoseinifar, S.H.; Ghosh, K.; Doan, H.V.; Beck, B.R.; Song, S.K. Lactic acid bacteria in finfish - an update. Front Microbiol 2018, 9, 1818. doi: 10.3389/fmicb.2018.01818. 
121. Gómez-Sala, B.; Hermida, J.F.; Cruza, P.E.H.; Izarra, L.M.C. Lactic acid bacteria in aquatic environments and their applications. In Lactic acid bacteria, Microbiological and functional aspects, 5th ed.; Vinderola, G.; Ouwehand, A.C.; Salminen, S.; von Wright, A., Eds.; Publisher: CRC Press, New York, USA, 2019. pp. 555-570.

122. Gómez-Sala, B.; Herranz, C.; Díaz-Freitas, B.; Hernández, P.E.; Sala, A.; Cintas, L.M. Strategies to increase the hygienic and economic value of fresh fish: biopreservation using lactic acid bacteria of marine origin. Int J Food Microbiol 2016, 223, 41-49. doi: 10.1016/j.ijfoodmicro.2016.02.005.

123. Sarika, A.R.; Lipton, A.P.; Aishwarya, M.S.; Dhivya, R.S. Isolation of a bacteriocin-producing Lactococcus lactis and application of its bacteriocin to manage spoilage bacteria in high-value marine fish under different storage temperatures. Appl Biochem Biotechnol 2012, 167, 1280-1289. doi: 10.1007/s12010-012-9701-0.

124. Wiernasz, N.; Cornet, J.; Cardinal, M.; Pilet, M.-F.; Passerini, D.; Leroi, F. Lactic acid bacteria selection for biopreservation as part of hurdle technology approach applied on seafood. Front Mar Sci 2017, 4, 119. doi: 10.3389/fmars.2017.00119.

125. Ngasotter, S.; Waikhom, D.; Mukherjee, S.; Devi, M.S.; Singh A.S. Diversity of lactic acid bacteria (LAB) in fermented fish products: a review. Int J Curr Microbiol Appl Sci 2020, 9, 2238-2249. https://doi.org/10.20546/ijcmas.2020.905.255.

126. Dapkevicius, M.L.E.; Batista, I.; Nout, M.J.R.; Rombouts, F.M.; Houben, J.H. Lipid and protein changes during the ensilage of blue whiting (Micromesistius poutassou Risso) by acid and biological methods. Food Chem 1998, 63, 97-102. doi: 10.1016/S03088146(97)00156-8.

127. Toppe, J.; Olsen, R.L.; Peñarubia, O.R.; James, D.G. Production and utilization of fish silage. A manual on how to turn fish waste into profit and a valuable feed ingredient or fertilizer. FAO: Rome, Italy, 2018; $28 \mathrm{pp}$.

128. Coello, N.; Montiel, E.; Concepcion, M.; Christen, P. Optimisation of a culture medium containing fish silage for L-lysine production by Corynebacterium glutamicum. Bioresour Technol. 2002, 85, 207-211. doi: 10.1016/s0960-8524(02)00084-6.

129. Ahuja, I.; Dauksas, E.; Remme, J.F.; Richardsen, R.; Løes, A.K. Fish and fish waste-based fertilizers in organic farming - with status in Norway: a review. Waste Manag 2020, 115, 95-112. doi: 10.1016/j.wasman.2020.07.025.

130. Haddadin, M.S.; Abdulrahim, S.M.; Hashlamoun, E.A.; Robinson, R.K. The effect of Lactobacillus acidophilus on the production and chemical composition of hen's eggs. Poult Sci 1996, 75, 491-494. doi: 10.3382/ps.0750491.

131. Panda, A.K.; Reddy, M.R.; Rama Rao, S.V.; Praharaj, N.K. Production performance, serum/yolk cholesterol and immune competence of white leghorn layers as influenced by dietary supplementation with probiotic. Trop Anim Health Prod 2003, 35, 8594. doi: 10.1023/a:1022036023325.

132. Kurtoglu, V.; Kurtoglu, F.; Seker, E.; Coskun, B.; Balevi, T.; Polat, E.S. Effect of probiotic supplementation on laying hen diets on yield performance and serum and egg yolk cholesterol. Food Addit Contam 2004, 21, 817-23. doi: 10.1080/02652030310001639530.

133. Asama, T.; Arima, T.H.; Gomi, T.; Keishi, T.; Tani, H.; Kimura, Y.; Tatefuji, T.; Hashimoto, K. Lactobacillus kunkeei YB38 from honeybee products enhances IgA production in healthy adults. J Appl Microbiol 2015, 119, 818-826. doi: 10.1111/jam.12889.

134. Yoshiyama, M.; Wu, M.; Sugimura, Y.; Takaya, N.; Kimoto- Nira, H.; Suzuki, C. Inhibition of Paenibacillus larvae by lactic acid bacteria isolated from fermented materials. J Invertebr Pathol 2013, 112, 62-67. doi: 10.1016/j.jip.2012.09.002.

135. Ramos, O.Y.; Salom_on, V.; Libonatti, C.; Cepeda, R.; Maldonado, L.; Basualdo, M. Effect of botanical and physicochemical composition of Argentinean honeys on the inhibitory action against food pathogens. LWT - Food Sci Technol 2018, 87, 457-463. doi: 10.1016/j.lwt.2017.09.014.

136. Wu, C.; Huang, J.; Zhou R. Genomics of lactic acid bacteria: Current status and potential applications, Critical Rev Microbiol 2017, 43, 393-404. doi: 10.1080/1040841X.2016.1179623.

137. Thumu, S.C.; Halami, P.M. Presence of erythromycin and tetracycline resistance genes in lactic acid bacteria from fermented foods of Indian origin. Antonie Van Leeuwenhoek 2012, 102, 541-551. doi: 10.1007/s10482-012-9749-4.

138. Li, Y.; Li, L.; Kromann, S.; Chen, M.; Shi, L.; Meng, H. Antibiotic resistance of Lactobacillus spp. and Streptococcus thermophilus isolated from Chinese fermented milk products. Foodborne Pathog Dis 2019, 16, 221-228. doi: 10.1089/fpd.2018.2516.

139. Câmara, S.P.A.; Dapkevicius, A.; Silva, C.C.G.; Malcata, F.X.; Dapkevicius M.L.N.E. Artisanal Pico cheese as reservoir of Enterococcus species possessing virulence and antibiotic resistance properties: implications for food safety. Food Biotechnol 2020, 34, 25-41. doi: 10.1080/08905436.2019.1710844.

140. Gevers, D.; Masco, L.; Baert, L.; Huys, G.; Debevere, J.; Swings, J. Prevalence and diversity of tetracycline resistant lactic acid bacteria and their tet genes along the process line of fermented dry sausages. Syst Appl Microbiol 2003, 26, 277-283. doi: 10.1078/072320203322346137.

141. van Reenen, C.A.; Dicks, L.M. Horizontal gene transfer amongst probiotic lactic acid bacteria and other intestinal microbiota: what are the possibilities? A review. Arch Microbiol 2011, 193, 157-168. doi: 10.1007/s00203-010-0668-3.

142. Werner, G.; Coque, T.M.; Franz, C.M.; Grohmann, E.; Hegstad, K., Jensen, L.; van Schaik, W.; Weaver, K. Antibiotic resistant enterococci - tales of a drug resistance gene trafficker. Int J Med Microbiol 2013, 303, 360-379. doi: 10.1016/j.ijmm.2013.03.001. 
143. Yang, C.; Yu, T. Characterization and transfer of antimicrobial resistance in lactic acid bacteria from fermented dairy products in China. J Infect Dev Ctries 2019, 13, 137-148. doi: 10.3855/jidc.10765.

144. Feld, L.; Bielak, E.; Hammer, K.; Wilcks, A. Characterization of a small erythromycin resistance plasmid pLFE1 from the foodisolate Lactobacillus plantarum M345. Plasmid 2009, 61, 159-170. doi: 10.1016/j.plasmid.2009.01.002.

145. D'Aimmo, M.R.; Modesto, M.; Biavati, B. Antibiotic resistance of lactic acid bacteria and Bifidobacterium spp. isolated from dairy and pharmaceutical products. Int J Food Microbiol 2007, 115, 35-42. doi: 10.1016/j.ijfoodmicro.2006.10.003.

146. Anadón, A.; Martínez-Larrañaga, M.R.; Martínez, M.A. Probiotics for animal nutrition in the European Union. Regulation and safety assessment. Regul Toxicol Pharmacol 2006, 45, 91-95.

147. Doron, S.; Snydman, D.R. Risk and safety of probiotics. Clinical Infect Dis 2015, 60(suppl.2), S129-S134. doi: 10.1093/cid/civ085. 